Безручко Олександр Вікторович, доктор мистецтвознавства, доцент,

Киӥвський національний університет культури імистецтв

\title{
МУЗИЧНА КІНОКОМЕДІЯ «ІНТРИГАН» ЯК ПЕРЕЛОМНИЙ МОМЕНТ У ДОЛІ УКРАЇНСЬКОГО РЕЖИСЕРА ТЕАТРУ І КІНО
} Я. I. УРIHOBA

У статті досліджено життєвий і творчий шлях украйнського театрального актора, режисера театру і кіно, сиенариста, заслуженого артиста Киргизької РСР, заслуженого діяча мистецтв Бурятської АРСР Якова Ісааковича Урінова та вплив на його подальшу долю музичної кінокомедї «Інтриган».

Ключові слова: Яків Урінов, кінематограф, театр, Київська кіностудія художніх фільмів, боротьба з формалізмом, «Інтриган», режисер, сиенарист.

В статье исследован жизненный и творческий путь украинского театрального актера, режиссера театра и кино, сценариста, заслуженного артиста Киргизской ССР, заслуженного деятеля искусств Бурятской АССР Якова Исааковича Уринова и влияние на его дальнейшую судьбу музыкальной кинокомедии «Интриган».

Ключевые слова: Яков Уринов, кинематограф, театр, Киевская киностудия художественных фильмов, борьба с формализмом, «Интриган», режиссер, сиенарист.

In this article investigational vital and creative way of the Ukrainian theatrical actor, stage-director of theatre and cinema, scenario writer, Honoured artist of the Kirghiz's Soviet Socialistic Republic, Honoured worker of arts of the Burat's Autonomous Soviet Socialistic Republic Yakiv Isaakovich Yrinov and influence on his further fate of musical comedy movie «Schemer».

Key words: Yakiv Yrinov, cinema, theatre, Kyiv film studio of feature films, fight against formalism, «Schemer», stage-director, scenario writer.

Актуальність дослідження зумовлена потребою вивчення творчої спадщини провідних українських митців, які з тих чи інших причин опинилися поза зоною уваги вітчизняних мистецтвознавців і культурологів.

Проблема, якій присвячується дослідження полягає в тому, що українськими мистецтвознавцями фактично не досліджувалося життя і творча діяльність українського театрального актора, режисера театру і кіно, сценариста, заслуженого артиста Киргизької РСР (1943), заслуженого діяча мистецтв Бурятської АРСР (1944) Якова Ісааковича Урінова (28.05.1898 - 13.08.1976).

Виходячи з проблеми, мета дослідження - дослідити та проаналізувати сторінки життя і творчої діяльності українського театрального актора, режисера театру і кіно, сценариста Я. Урінова. 
Я. Урінов після закінчення 1921 р. акторського і режисерського відділення Київської державної театральної студії спочатку працював у театрі, а 1925 р. перейшов до кінематографу: спочатку був асистентом російського і радянського режисера, заслуженого діяча мистецтв РРФСР (1935), заслуженого діяча мистецтв Узбецької РСР (1943) Якова Олександровича Протазанова (4.02.1881 - 8.08.1945) на стрічці «Процес про три мільйони» (1926), потім в Україні як режисер-постановник (а в деякий фільмах ще й автор сценарію) зняв фільми «Матрос Іван Гапай» (1929, фільм не зберігся), «Вогняний рейс» (1930), «Дві зустрічі» (1932), «Степові пісні» (1934) та «Інтриган» (1935). Зняті в Росії фільми будуть названі наприкінці статті.

Перш за все, треба розібратися з правильністю написання прізвища Я. Урінова. У російськомовних джерелах він проходить як «Уринов» [4; 7, с. 1150], в українськомовних зустрічаються два варіанти написання: «Урінов» [3, с. 61; 17, с. 3] та «Уринов» [8]. Проте автор вважає більш правильним вживати «Урінов».

В енциклопедичній статті «Уринов Яков Исаакович», що була надрукована ще за радянських часів у другому томі «Кинословаря» перші фільми митця, відзняті Я. Уріновим в Україні у 30-х рр. ХХ ст. взагалі не згадуються [7, с. 1150]. Натомість першим фільмом режисера-постановника Я. Урінова вказано повнометражний документальний фільм про глухонімих дітей «Вони будуть говорити», відзнятий митцем 1963 р. на кіностудії «Центрнаучфільм» [7, с. 1150]. Така ж інформація в наш час виставлена на спеціалізованому російському сайті з красномовною назвою «Кино-театр» [14].

У надзвичайно популярній серед сучасних вітчизняних кінофілів книжці «Історія українського кінематографа. 1896-1995» французького кінознавця українського походження Любомира Госейка згадуються лише два останні українські фільми Якова Урінова «Степові пісні» [3, с. 61, 76-77] та «Інтриган» [3, с. 84].

В українському варіанті «Вікіпедії» першим фільмом Я. Урінова помилково вказано «Вогняний рейс» (1930) [16], у російському варіанті «Википедии» правильно вказано перший фільм Якова Урінова та рік виходу, проте зроблена помилка в назві «Матрос Іван Галай» (1929) [15]. Автором статті завдяки опрацюванню тогочасної фахової преси з'ясована точна назва першої стрічки Я. Урінова, відзнятої в якості режисера-постановника-«Матрос Іван Гапай» [8].

Вихід першої картини Я. Урінова «Матрос Гапай» висвітлювався в четвертому номері українського журналу «Кіно» за 1929 р.: «Тематика горожанської (громадянської. - О. Б.) війни ще й досі є одним з найбільших полотен, що його намагаються використати сценаристи й режисери. Фільм «Матрос Гапай», що його ставив для Совкіно режисер Уринов, незабаром має з'явитися в прокаті. В головних ролях знімались: нар. арт. Республіки Блюменталь-Тамарина, Турвух, засл. арт. Петровський тощо» [8]. Ілюструвалася ця невеличка стаття кадром з фільму, на якому були зображені актори, що сміються.

Любомир Госейко зазначав, що 1933 р. внаслідок Голодомору річний обсяг українського кіновиробництва зменшився більш аніж на 60\%: «Із 18 фільмів, які ставлять після неодноразових переробок, закінчено лише половину. Це, зокрема, звукові - «Зона» Михайла Капчинського, яка вийде в новій версії 1935 р. під назвою «Остання ніч», «Каховський плацдарм» Олександра Штрижака», «Любов» Олександра 
Гавронського й Ольги Улицької, «Коліївщина» Івана Кавалерідзе, «Степові пісні» Якова Урінова...» [3, с. 76-77].

Улітку 1933 р. в московській газеті «Кино» Г. Григорьєв повідомляв про фільми, які знімаються на Київській кінофабриці «Українфільм»: «Режиссер Я. Уринов снимает сейчас картину «Степные песни» по сценарию Уринова и Леонидова на тему о нарастании революционного движения на селах Кубани и Дона в гражданскую войну. В главных ролях снимаются Гайдаров, Гзовская, Зубарев и др. Музыку пишет композитор Ревуцкий. Сейчас проходят съемки огромных натурных построек-ярмарка. В эпизоде участвует огромная массовка - десятки возов, цыгане со своим «інвентарем» и т.д. «Степные песни» выйдут в 3 квартале (1933 р. - О.Б.)» [4].

Ця стрічка Я. Урінова, як розповідалося одній з московських газет, «о солдате царской службы, инвалиде, георгиевском кавалере, мелком крестьянине, чье сознание перековывается с приближением пролетарского Октября» [9].

Фільму Якова Урінова «Степові пісні» (1933) Любомир Госейко приділяв великого значення, тому згадував у книжці «Історія українського кінематографа. 18961995» в якості знакової стрічки однієї з трьох категорій у першій половині 30-х рр.: «Зі 110 стрічок, що їх було випущено в Україні з 1930 до 1935 р., створено близько двадцяти звукових за трьома категоріями: натуралістичні чи експериментальні фільми на кшталт «Симфонії Донбасу» (1930) Дзиги Вертова; фільми з музичною ілюстрацією, занадто алегоричні чи емоційні, як-то «Степові пісні» (1933) Якова Урінова; й, нарешті, оригінальні ігрові картини, як, скажімо, «Фронт» (1931) Олександра Соловйова та «Іван» (1932) Олександра Довженка» [3, с. 61].

Проте не все було добре з цією стрічкою Я. Урінова. Восени 1933 р. у московській газеті «Кино» Л. Мітницький віднайшов «нацдемівські бацили» в картинах Київської кінофабрики П. Коломойцева «Межигір'я», «Червона хустинка» Л. Френкеля, «Любов» Я. Гавронського та «Степові пісні» Я. Уринова: «Этот сценарий представляет для режиссера много трудностей и в него тихой сапой вкрались нацдемовские бациллы. С помощью фабричной общественности режиссеру, который в поте лица трудится над этой картиной, удастся (судя по разрозненным пока частям) прийти к намеченной цели» [9].

Утім, як видно з останньої фрази, перспективи у стрічки «Степові пісні» Я. Урінова були чудові, як, до речі, й у нового фільму митця з робочою назвою «Найсолодший політ», який перед виходом на екрани отримав назву «Інтриган».

Не випадково помічник керівника ГУКФ СРСР К.Ю. Юков у патетичній статті «Українська кінематографія на підйомі» серед багатьох картин Київської кінофабрики відзначав й нову стрічку Я. Урінова «Найсолодкіший політ» («Інтриган»): «В настоящее время заметно начало большого творческого подъема. На Киевской и Одесской фабриках идет напряженная постановочная работа. В Киеве режиссер И. П. Кавалеридзе заканчивает свой большой эпопейный фильм «Прометей». Интенсивную съемочную работу ведут режиссер Луков («Я люблю»), режиссер Шмин и Ильинский («Однажды летом»), А. Роом («Строгий юноша»), режиссер Уринов («Сладчайший полет»)» [19].

У музичній кінокомедії Я. Урінова розповідалося про долю іноді аж занадто веселого курсанта школи молодих пілотів, який під час одного з навчальних польотів 
на низькій висоті перелякав табун коней з розташованої неподалік військової частини радгоспу. За цей хуліганський вчинок він може не отримати диплома, що фактично «закриває небо» та зводить нанівець омріяне майбутнє «сталінського сокола». Проте завдяки поверненню цим курсантом до радгоспівських конюшень племінного жеребцявтікача «Інтригана», який дуже полюбляє цукор (чим власне й скористалися курсант 3 подружкою Ольгою), все закінчується для хлопця хеппі-ендом.

Стрічка «Інтриган» була успішно здана Яковим Уріновим кінокерівництву восени 1935 р. У першому номері журналу «Радянське кіно» за 1936 р. $з$ метою реклами фільму для пересічного глядача було вміщено кадр з фільму«Інтриган», під яким було написано: «Арт. П. Масоха в ролі студента авіаінституту. 3 фільму «Інтриган» Реж. Урінов, оператор Вовченко» [1].

За словами Л. Госейка: «Саме 1935 р. більшість фільмів, знятих в Україні, стають звуковими. «Інтриган», музична комедія Якова Урінова, й «Остання ніч» Михайла Капчинського, перемонтована версія «Зони» з 1933 р., доводять, що нові технології ще далеко не освоєні» [3, с. 84].

Проте проблема цієї стрічки Я. Урінова була не в недостатньому опануванні режисером звукових технологій, а, перш за все, в тому, що на початку 1936 р. у Радянському Союзі розпочалася широкомасштабна боротьба проти «формалізму» $\mathrm{i}$ «натуралізму». Для того, аби всі трудящі, і насамперед самі митці, зрозуміли, що ж таке формалізм у мистецтві, було випущено навіть збірники з розділами, присвяченими різним видам мистецтва (кінематограф, музика, театр, архітектура, образотворче мистецтво тощо). Такі збірники були перекладені всіма мовами Радянського Союзу. Зокрема, в Україні 1936 р. вийшов збірник українською мовою «Проти формалізму, натуралізму і спрощенства в мистецтві» [11], у якому після оприлюднення програмної статті наведено скорочену стенограму промови голови новоствореного Комітету у справах мистецтв при Раднаркомі СРСР П. Керженцева на пленумі ЦК Спілки робітників мистецтв СРСР «За велике мистецтво соціалізму», що у повному варіанті й російською мовою була надрукована в газеті «Правда» 16 лютого 1936 р.: «Утворення Комітету у справах мистецтв - велика політична подія, яка має значення не тільки для робітників мистецтв, але і для всього культурного фронту» [11, с. 81].

У добу боротьби з формалізмом стрічка Якова Урінова «Інтриган» разом 3 фільмами Івана Кавалерідзе «Прометей» та Абрама Роома «Суворий юнак» була оголошена формалістичною, та, відповідно, «покладена на полицю». Незважаючи на тогочасні заборони вищезгадані фільми збереглися до наших днів.

Нагадаємо, що спочатку фільм Я. Урінова хвалить друга людина серед найвищого кінематографічного керівництва СРСР (помічник керівника ГУКФ СРСР К. Юков [19]), проте невдовзі ще вище керівництво, а саме керівник радянської кінематографії Б. Щумяцький у виступі «Проти формалізму і натуралізму» нищівно громив ту ж саму стрічку Я. Урінова, як, до речі, і роботи А. Роома та І. Кавалерідзе: «В фильме «Интриган», например, изображается нелепая история с конем, который мешает любви, расстраивает свидание и, наконец, исчезает из конюшни. В чем порок этой вещи? Тема могла послужить основанием для неплохой и смешной комедии, но растянутость фильма, плохая актерская игра, сусальность режиссерской трактовки иплохая музыкагубят фильм» [12]. 
Зрозуміло, що після цього найвищий український кінематографічний керівник новий очільник «Українфільму» М.П. Ткач в контексті критики фільму А. Роома «Суворий юнак» вже апріорі серед поганих називав «Інтригана»: «Печальная история. Она тем печальнее, что такие истории происходят в киевской студии далеко не впервые. «Прометей». . «Интриган».. « «Однажды летом». . «Счастливый финиш».. Цепь неудач. Серые, идейно и художественно слабые, а то и совершенно негодные вещи. И вот теперь «Строгий юноша», один из «ведущих» фильмов в плане студии в 1935 г.» [13].

Ця стаття називалася «“Суворий юнак” і несуворі керівники». У ній Ткач робив винуватцем вищеназваних стрічок не лише режисерів-постановників, але й свого попередника Левіта та директора Київської кінофабрики Нечесу. Доповідь керівника Українфільму Марка Петровича Ткача про «шкідників» і «ворогів» за тогочасною традицією широко обговорювалися на Київській кіностудії, про що повідомлялось у всесоюзній газеті «Кино»: «На двух заседаниях, длившихся до поздней ночи, творческие работники киевской киностудии обсуждали доклад начальника Украинфильм тов. М. П. Ткача о деятельности троцкистко-зиновьевского террористического центра» [6].

На цих зібраннях були вимушені виступати з викривальними промовами (хто щиро, а хто і з страху стати наступним «ворогом народу») більшість працівників Київської кіностудії-новий директор С. Орелович, режисери О. Довженко, Л. Луков, Г. Гричер, Л. Френкель, М. Каростін, Ф. Лопатинський, Л. Бодик та ін. Утім політично правильні виступи не допомогли новому керівництву Київської кінофабрики, усього через рік після «викриття» попередників будуть заарештовані керівник «Українфільму» М. Ткач і директор Київської кіностудії С. Орелович.

Проте це відбудеться 1937 р., а у 1936 р. в головному журналі української кінематографії «Радянське кіно» одним зі звинувачень нещодавно заарештованому керівнику «Українфільма» Левіту було виробництво фільму «Інтриган»: «Понад два роки художньо-виробничим управлінням «Українфільм» керував троцькістський дворушник Левіт. Він застосував особливу, гідну дворушника тактику у своїй роботі- не випинатися там, де політично гостра ситуація, щоб, мовляв, не помітили, не зірвали машкари - i тишком-нишком робити своє. Під його безпосереднім керівництвом зроблені такі політично шкідливі фільми, як «Інтриган», «Суворий юнак». Викинуто в повітря 2,5 мільйонів державних грошей» [2].

Так само і директорові Київської кінофабрики П. Нечесі дорікали, що він «втратив більшовицьку пильність і припустив провал виробництва фільмів, під «керівництвом» якого студія зробила «Прометей», «Суворий юнак», «Інтриган»» [10].

Режисер та сценарист Одеської, а потім і Київської кінофабрики С. Лазурін, який був автором сценарію стрічки «Інтриган», під час триденного зібрання творчого активу Київської кінофабрики на початку 1936 р., присвяченого розбору «формалістичних помилок» у фільмі І. Кавалерідзе «Прометей» був вимушений виправдовуватися за власні «помилки» в сценарії «Інтригана», зокрема дивне враження справила самокритична частина доповіді Лазуріна: «У моєму сценарії «Інтриган» жива дійсність потонула і у видуманій з голови комедійній схемі. Люди в сценарії намічені слабше, ніж літаки і кінь. Режисер поглибив мої помилки і зробив оперету просто жанром, ще більше підкресливши умовні характери i, крім того, ще вніс у фільм свій поганий смак». 
Будучи мистецьким керівником студії і переглядаючи зняті шматки фільму, Лазурін бачив, що таке оперета. Нарешті, приймаючи картину, він бачив, що режисер «поглибив його помилки». Чому ж, як мистецький керівник, він тоді ж не заявив, що фільм «нтриган»- брак? Про це ні слова.

Далі, Лазурін, кажучи про картину «Прометей», бачить основну помилку керівництва і творчої секції в тому, що «керівництво студії і творчий колектив не були наполегливі до кінця у спробах примусити т. Кавалерідзе переоцінити його роботу над «Прометеєм» і зрозуміти допущені помилки» [17, с. 2].

Інші творчі працівники також не оминали у своїх виступах фільм Я. Урінова «Інтриган»: «Як відповідь на це, у значній ча сстині виступів творчі працівники сту дії наводили приклад 3 картиною «Інтриган» (реж. Урінов) як абсолютне ігнорування дирекцією студії думки творчих працівників.

Бюро творчої секції дало негативну оцінку картині. Дирекція позитивно оцінила фільм «Інтриган». Наслідки відомі» [17, с. 3].

Фільм Я. Урінова «Інтриган», як і А. Роома «Суворий юнак» та I. Кавалерідзе «Прометей» у другій половині 30-х рр. ХХ ст. в українській кінематографії стали взірцем (якщо так можна сказати) поганих фільмів. Так, наприклад, М. Ятко в статті про невдачу фільму А. Окунчікова і Л. Бодіка «Справжній товариш» вживав такі фрази: «Після ряду виробничих поразок (“Інтриган”, “Прометей”, “Суворий юнак”)» [20, с. 12], «ще одна ланка в ланцюгу невдач і поразок київської кіностудії, що відкриваються “Інтриганом”» [20, c. 15].

У вересні 1937 р. Г. Затворницький серед групи «ворогів народу», що працювали на Київській кіностудії та в Київському державному інституті кінематографії називав і прізвище Я. Урінова: «Відомо, що в Київському держаному інституті кінематографії в складі лектури довгий час орудували викриті вороги - різні гавронські, врони, мухіни та ін., а також виявлено безграмотних, далеких від кіномистецтва людей, як Файнберга, Урінова (виділено мною. - О. Б.), Юнаківського, Панкришева та ін.» [5].

Зазначимо, що так звані проробляння і чистки політично важливих для радянської влади кінофабрик, інститутів тощо, були постійними і планомірними. Вони широко анонсувалися в пресі. Так, про одну із «чисток» Київської кінофабрики повідомлялося у фабричній газеті «За більшовицький фільм»: «Чистка розпочинається через кілька днів!» [18, с. 1].

Розглянемо варіанти подальшої долі режисерів, які потрапили під маховик такої масштабної критики. Після багатоденних «формалістичних чисток» за фільм «Прометей» (1935) український скульптор, кінорежисер, драматург, сценарист, художник кіно, народний артист УРСР (1969) І. П. Кавалерідзе (13.04.1887 - 3.12.1978) не зміг завершити задуману ним трилогію «Коліївщина» - «Прометей»- «Дніпро», а став на Київській кіностудії знімати фільми-опери «Наталка-Полтавка» (1936) та «Запорожець за Дунаєм» (1937).

Автор «формалістичного фільму» «Суворий юнак» (1936, інші назви «Дискобол», «Комісар побуту», «Чарівний комсомолець») російський кінорежисер, сценарист, актор, кінопедагог Абрам Матвійович Роом (28.06.1894 - 26.07.1976) реабілітувався на Київській кіностудії двома політично важливими «оборонними» 
стрічками «Ескадрилья № 5» (1939) та «Вітер зі Сходу» (1940), після чого повернувся до Росії, де активно та успішно знімав, за що й отримав звання народного артиста РРФСР (1965) та дві Державні (Сталінські) премії СРСР за стрічки «Нашестя» (1946, poc. - «Нашествие») та «Суд честі» (1949).

Водночас Яків Ісаакович Урінов після нищівної критики свого останнього знятого на Київській кіностудії фільму «Інтриган» (1935), залишив кінематограф майже на півтора десятка років. Наприкінці 30-х - у першій половині 40-х рр. ХХ ст. Яків Урінов працював актором і режисером Киргизького російського театру, за що отримав звання заслуженого артиста Киргизької РСР (1943) та заслуженого діяча мистецтв Бурятської АРСР (1944) [14]. Повернувся до кінорежисури Я. Урінов 1948 р. Тільки, по-перше, став знімати не в Україні, а в Росії, а, по-друге, не ігрові фільми, а науково-популярні. Я. Урінов працював на кіностудії «Центрнаучфільм», де був режисером-постановником стрічок: «Вони будуть говорити» (1963), «Андрюша думає» (1963), «Роббі» (1964), «П’єр і Жаннте» (1964), «Містер Усезнайко» (1966), «Дядя Ернест» (1967) тощо $[7$, c. 1150$]$.

Підсумовуючи вищевикладене, можна зазначити, що поставлені наукові завдання виконані: досліджено життєвий і творчий шлях Я. Урінова в Україні; визначено правильність написання прізвища митця українською мовою; з'ясовано правильну назву першого фільму Якова Урінова, знятого в якості режисера-постановника та рік виходу на екрани; наведено список режисерських робіт митця на Київській кіностудії художніх фільмів у 20-30-х рр. ХХ ст. та на «Центрнаучфільмі» у 60-х рр. ХХ ст.; проаналізовано причини заборони стрічки «Інтриган» внаслідок боротьби з формалізмом в СРСР у другій половині 30-х рр. ХХ ст. та їі вплив на подальшу долю Якова Ісааковича Урінова.

Тим не менш, перспективи наукових розвідок залишаються широкими, оскільки майже не дослідженими залишаються життя і творча діяльність Я. Урінова з 1936 до 1948 p.

\section{Jimepamypa:}

1. [Арт. П. Масоха в ролі студента авіаінституту] // Радянське кіно. - 1936. -№ 1. - С. 52. 2. Вище більшовищьку пильність : [ред. ст.] // Радянське кіно. - 1936. - № 9. - С. 2. 3. Госейко Л. Історія українського кінематографа. 1896-1995 : пер. із фр. / Л. Госейко. - Київ : KINOКОЛО, 2005. - 464 с. 4. Григорьев Г. На Киевской кинофабрике «Украинфильм» / Г. Григорьев // Кино. - 1933. - 16 июня. 5. Затворнищький Г. Шлях творчого зросту / Г. Затворнищький// За більшовицький фільм. - 1937. - 4 вересня. 6. И. Л. Ответить делом! / И. Л. // Кино. - 1936. 11 сентября. 7. Кинословарь : в 2 m. / гл. ред. С. И. Юткевич. - Москва : Советская энииклопедия, 1970. - T. 2 : М-Я, Дополнения. - 1424 с. 8. «Матрос Гапай» : [ред. cm.] // Кіно. - 1929. - № 4. - С.14. 9. Митницкий Л. Лицом к вчерашему дню / Л. Митницкий // Кино. - 1933. - 6 октября. 10. Презрені вороги народу : [ред. ст.] // Радянське кіно. 1937. - № 1-2. - С. 5. 11. Проти формалізму, натуралізму і спрощенства в мистецтві. Киї, 1936. - 137 с. 12. Против формализма и натурализма. Из доклада тов. Б.З. Шумячккого // Кино. - 1936. - 6 марта. 13. Ткач М. «Строгий юноша» и не строгие руководители / М. П. Ткач // Кино. - 1936. - 28 июля. 14. Уринов Яков Исаакович. [Електронний ресурс]. Режим доступy: http://www.kino-teatr.ru/kino/director/sov/20158/bio/ 15. Уринов Яков 
Исаакович. Материал из Википедии - свободной энџиклопедии. Русскийязык. [Електронний pecypc].-Pежим достуny: https://ru.wikipedia.org/wiki/\%D0\%A3\%D1\%80\%D0\%B8\% D0\% $B D \% D 0 \% B E \% D 0 \% B 2, \% D 0 \% A F \% D 0 \% B A \% D 0 \% B E \% D 0 \% B 2 \_\% D 0 \% 98 \% D 1 \% 81 \% D 0 \% B 0$ $\%$ D0\%B0\%D0\%BA\%D0\%BE\%D0\%B2\%D0\%B8\%D1\%87 16. Урінов Яків Ісаакович. Матеріал з Вікіпедї- вільної енциклопедії. Українська мова [Електронний ресурс]. - Режсим docmyny: https://uk.wikipedia.org/wiki/\%D0\%A3\%D1\%80\%D1\%96\%D0\%BD\%D0\%BE\%D0\% B2_\%D0\%AF\%D0\%BA\%D1\%96\%D0\%B2_\%D0\%86\%D1\%81\%D0\%B0\%D0\%B0\%D0\%BA\% D0\%BE\%D0\%B2\%D0\%В8\%D1\%8717. У роботі Київькоїстудї̈потрібна більшовищька ідійова самокритика : [ред. ст.] // Радянське кіно. - 1936. -№ 4. - C. 1-3. 18. [Чистка розпочинається через кілька днів!] // За більшовицький фільм. - 1933. - 2 вересня. 19. Юков К. Украинская кинематография на подъеме / К. Ю. Юков // Кино. - 1935. - 23 июля. 20. Ятко М. Легковажність до виробництва фільму «Справжній товариш» / М. Ятко // Радянське кіно. - 1936. - № 10. - С. 12-15. 